\title{
Grundtvig-Selskabet af 8. september 1947: Årsberetning 2009
}

\author{
Af Peter Balslev-Clausen
}

Grundtvig-Selskabets årsmøde 2008 blev afholdt lørdag den 15 . november kl. 9.30 - 16.00 i Vartov, Farvergade 27, København, med Ole Vind som dirigent. Ved de ordinære valg blev Ulrik Overgaard genvalgt til styrelsen, og A. M. Allchin, Harry Aronson, Sune Auken og Marie Louise Nygaard blev genvalgt og Jens Holger Schjørring, Anders Holm, Hanne Sanders, Harry Haue og Synnøve Sakura Heggem nyvalgt til repræsentantskabet. Som revisor genvalgtes Bjarne Hansen, Gelsted. I forbindelse med årsmødet afholdtes et seminar om "Grundtvig og det græske", hvor Flemming Lundgreen-Nielsen talte om "Grundtvig og græsk mytologi". Jørgen I. Jensen talte om "Det jødiske og græske hos Grundtvig". Seminaret sluttede med et besøg på Thorvaldsens Museum, hvor museumsinspektør Margrethe Florian i forbindelse med en rundvisning i samlingerne talte om Thorvaldsens brug af mytologiske motiver.

Efter årsmødet konstituerede styrelsen sig med Peter BalslevClausen som formand, Flemming Lundgreen-Nielsen som næstformand, Erik Jakob Petersen som kasserer, Ulrik Overgaard som sekretær og Kim Arne Pedersen som ansvarshavende redaktør for Grundtvig-Studier.

Styrelsen har i det forløbne år holdt møder 17. april, 29. juni og 9. oktober.

Grundtvig-Studier 2008 indeholdt artikler af Anders Eskedal ("Om Grundtvig og G. P. Brammer”), S. A. J. Bradley (" "Denne Gaade er godt gjort': Grundtvig's encounter with the riddles of the Exeter Book"), Flemming Lundgreen-Nielsen ("N. F. S. Grundtvig: RimBrev til Nordiske Paarørende, 1832. Tekstkritisk og kommenteret udgave"), K. E. Bugge med bilag ved Bjørn Krab-Johansen ("Nogle grundbegreber i Grundtvigs pædagogiske tanker"), Aage Schiøler ("Spænding, samspil og frisættelse: En undersøgelse af forholdet mellem inkarnation og eskatologi i Grundtvigs salme 'Midt iblandt os er Guds Rige"”), Marianne Stølen ("Om Grundtvigs sanges liv i Nordamerika"), Vagn Wåhlin og Kim Arne Pedersen ("Education for the people: Concepts of Grundtvig, Tagore, Gandhi and Freire") og Flemming Lundgreen-Nielsen ("Tilføjelse til 'Grundtvig og censuren' i Grundtvig-Studier 2007'). Grundtvig-Studiers redaktion består af den ansvarshavende redaktør Kim Arne Pedersen, Flemming LundgreenNielsen, S. A. J. Bradley, Ulrik Overgaard og Peter Balslev-Clausen. 
Der er siden sidste årsmøde, 23. juli 2009, indgået en samarbejdsaftale omkring udgivelsen af Grundtvig-Studier med Grundtvig Centeret ved centerleder Michael Schelde. Aftalen indebærer, at de to parter nedsætter en redaktion for Grundtvig-Studier bestående af tre repræsentanter fra Grundtvig-Selskabet og to repræsentanter fra Grundtvig-Centeret. Aftalen åbner også for andre mulige fælles initiativer mellem de to involverede parter.

Det er naturligt igen i år i forbindelse med årsmødet at takke Grundtvig-Selskabets samarbejdspartnere, ikke mindst selskabets samarbejdspartnere i Vartov: Grundtvigsk Forum repræsenteret af Sekretariatsleder Hans Grishauge og sekretær Kirsten Grishauge, Grundtvig-Biblioteket med bibliotekar Liselotte Larsen og GrundtvigAkademiet ved akademileder Birgitte Stoklund Larsen.

Grundtvig-interessen er uformindsket, og der er mere end nogensinde brug for det frie forsknings- og debatforum, som GrundtvigSelskabet også fremover vil være! 